\title{
Management of pennycress as a winter annual cash cover crop. A review
}

\author{
Julija A. Cubins ${ }^{1} \cdot$ M. Scott Wells ${ }^{1}$ (I) $\cdot$ Katherine Frels ${ }^{1} \cdot$ Matthew A. Ott $^{1} \cdot$ Frank Forcella $^{2} \cdot$ Gregg A. Johnson $^{1}$. \\ Maninder K. Walia ${ }^{1} \cdot$ Roger L. Becker ${ }^{1} \cdot$ Russ W. Gesch ${ }^{2}$
}

Accepted: 5 August 2019/Published online: 4 September 2019

(C) The Author(s) 2019

\begin{abstract}
Agriculture in the Upper Midwest of the USA is characterized by a short growing season and unsustainable farming practices including low-diversity cropping systems and high fertilizer inputs. One method to reduce the magnitude of these problems is by integrating a winter annual into the summer-annual-dominant cropping system. For this reason, pennycress (Thlaspi arvense) has garnered interest in the agricultural community due to its winter annual growth habit and potential for industrial oil production, making it an ecologically and economically desirable crop. Despite decades of research focusing on pennycress as an agricultural weed, little is known about its best management practices as an intentionally cultivated crop. The majority of agronomic research has occurred within the past 10 years, and there are major gaps in knowledge that need to be addressed prior to the widespread integration of pennycress on the landscape. Here we review relevant agronomic research on pennycress as a winter annual crop in the areas of sowing requirements, harvest, seed oil content, seed oil quality, cropping strategies, ecosystem services, and germplasm development. The major points are as follows: (1) there is little consensus regarding basic agronomic practices (i.e., seeding rate, row spacing, nutrient requirements, and harvest strategy); (2) pennycress can be integrated into a corn (Zea mays)soybean (Glycine max) rotation, but further research on system management is required to maximize crop productivity and oilseed yields; (3) pennycress provides essential ecosystem services to the landscape in early spring when vegetation is scarce; (4) breeding efforts are required to remove detrimental weedy characteristics, such as silicle shatter and high sinigrin content, from the germplasm. We conclude that pennycress shows great promise as an emergent crop; however, current adoption is limited by a lack of conclusive knowledge regarding management practices and future research is required over a multitude of topics.
\end{abstract}

Keywords Alternative cropping systems $\cdot$ Agronomic management $\cdot$ Corn-soybean rotation $\cdot$ Ecosystem services $\cdot$ Germplasm development $\cdot$ Pennycress $\cdot$ Industrial oilseeds

\section{Contents}

1. Introduction

2. Sowing requirements

2.1 Fertilization requirements

3. Harvest

3.1 Seed yield

4. Seed oil content and quality

5. Cropping strategies

M. Scott Wells

mswells@umn.edu

1 Department of Agronomy and Plant Genetics, University of Minnesota, 1991 Upper Buford Circle, Saint Paul, MN 55108, USA

2 North Central Soil Conservation Research Laboratory, USDA-ARS, 803 Iowa Avenue, Morris, MN 56267, USA
6. Ecosystem services

7. Germplasm development

8. Conclusion

Acknowledgments

References

\section{Introduction}

Pennycress (Thlaspi arvense), also known as field pennycress, fanweed, French-weed, and stinkweed, is an emerging Brassicaceae (mustard family) oilseed crop that was first identified for production in 1944 (Clopton and Triebold 1944). Despite its point of origin in Eurasia, naturalized accessions of pennycress have been found throughout temperate regions of the USA and Canada indicating regional adaptation (Holm et al. 1997; Warwick et al. 2002; Phippen and Phippen 2013) 
Fig. 1 Pennycress overwinters as a rosette providing late fall and early spring ground cover when summer annuals are not on the landscape. Ecological benefits of winter cover include suppression of early spring weeds and a reduction in nutrient runoff due to early spring precipitation and snowmelt. Photo by Julija A. Cubins

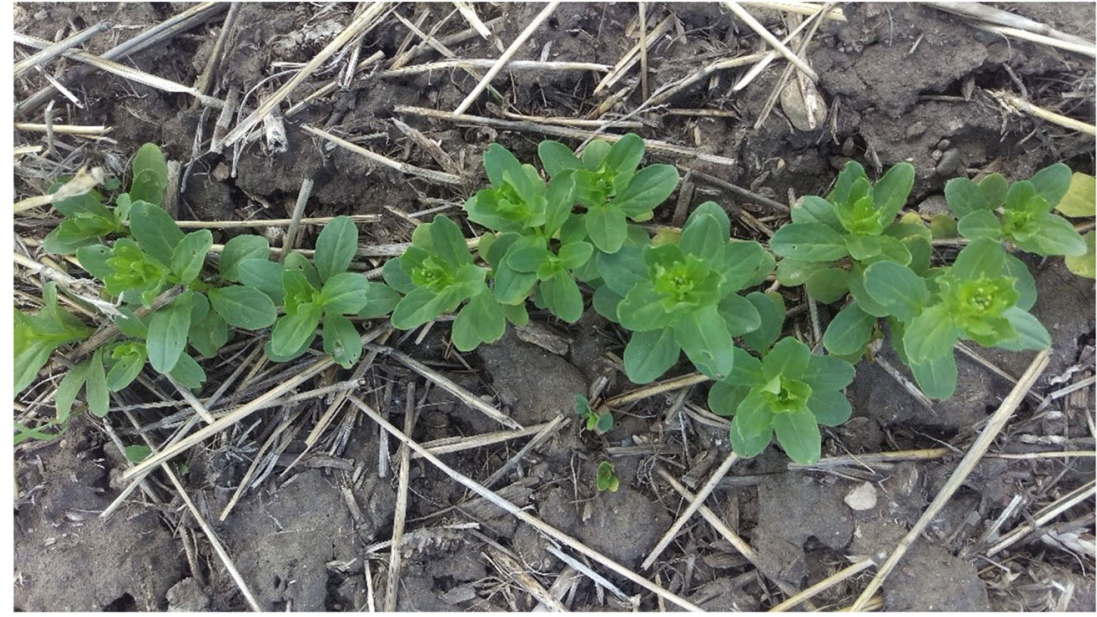

and winter survivability (Saarinen et al. 2011). Interest in pennycress as an agricultural crop (Figs. 1 and 2) has been spurred by the demand for alternative land use to mitigate prominent, but unsustainable, farming practices in the Upper Midwestern USA (Heaton et al. 2013; Sindelar et al. 2017). Unlike many winter annual crops grown in the Upper Midwest, pennycress seed can be pressed for oil and provide near-term economic benefits to growers (Moser et al. 2009a, b; Moser 2012). While research has been conducted on pennycress as a persistent weed in canola (Brassica napus) and wheat (Triticum aestivum) for decades (Best and McIntyre 1975; Warwick et al. 2002), earnest development of agronomic management practices for pennycress as a cultivated crop did not begin until its oil was evaluated as a potential biodiesel feedstock in 2009 (Moser et al. 2009a, b) followed by the sequencing of the genome in 2015 (Dorn et al. 2015). More research is necessary to determine the agronomic best management practices given the recent emergence of pennycress as a crop. The objective of this review was to compile and summarize current agronomic research on pennycress and identify gaps in knowledge for future research.

\section{Sowing requirements}

Optimum planting date for pennycress varies significantly between regions. The majority of research related to pennycress planting date has occurred in the Upper Midwest, and there is evidence across growing locations in this region that early September sowing dates correspond to better establishment than late fall or early spring planting dates (Phippen et al. 2010b; Gesch et al. 2016; Dose et al. 2017). However, in the Mediterranean climates, pennycress is not sown until early October, and, in some cases, may not be planted until early November (Royo-Esnal et al. 2015, 2017; Gesch et al. 2016; Zanetti et al. 2018). In the Upper Midwest, early fall sowing dates correspond to higher soil temperatures, which favors better germination and a longer vegetative growth period prior to winter frost (Phippen et al. 2010b; Royo-Esnal et al. 2017). In comparison to late fall planting dates, early September planting dates also resulted in higher yields and earlier harvest dates (Dose et al. 2017), which is favorable for double-

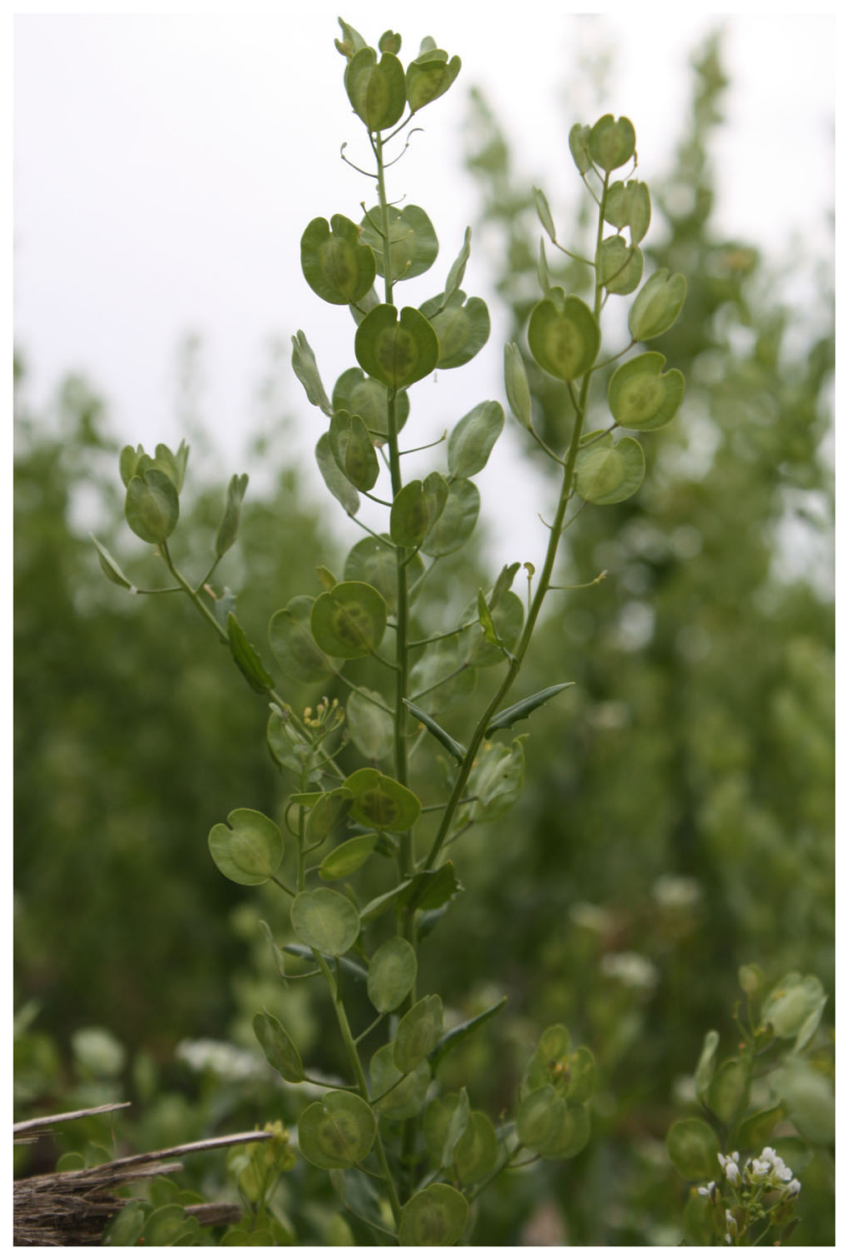

Fig. 2 Pennycress line used to assess agronomic properties in field production. Prior to ripening, silicles and seeds have reached their full size but have not begun to mature. Photo by Rebekah J. Carlson 
cropping (Phippen et al. 2010b). In extreme cases, late planting dates can decrease the chance of flowering and, thus, reduce or eliminate seed production in a given year (Milberg and Andersson 1994).

There is little cohesion in regard to planting strategy (Table 1). In Minnesota alone, planting rates ranged from 5.5 to $16.8 \mathrm{~kg} \mathrm{ha}^{-1}$ (Eberle et al. 2015; Johnson et al. 2015, 2017; Gesch et al. 2016; Dose et al. 2017) with little consistency across research studies. A study conducted in western Illinois directly compared three different seeding rates, 1.1, 2.2 , and $4.9 \mathrm{~kg} \mathrm{ha}^{-1}$, but researchers were not able to draw conclusions regarding optimal planting rate (Phippen et al. 2010a).Seeding method was also evaluated, and it was determined that drilled plots had better stand establishment and higher yields than broadcasted plots regardless of seeding rate (Phippen et al. 2010a). Pennycress is positively photoblastic (Hazebroek and Metzger 1990a), and a single study concluded that broadcast seeding enhanced pennycress germination due to the increased exposure of seed to light (Carr 1993). Despite this finding, the majority of recent studies are consistent with the results of Phippen et al. (2010a) and have sowed pennycress around a depth of $1 \mathrm{~cm}$ using a seed drill (Table 1).

Pennycress is very susceptible to environmental influences, and water availability is the major limiting factor to germination and development (Royo-Esnal et al. 2015; Gesch et al. 2016). Germination occurs most readily in cool, wet conditions (Hazebroek and Metzger 1990a, b; Johnson et al. 2015; Royo-Esnal et al. 2015, 2017), and pennycress requires between 25 and $40 \mathrm{~mm}$ of water to germinate (Royo-Esnal et al. 2015; Johnson et al. 2017). Royo-Esnal et al. (2015) noted that only $5 \%$ of seedlings emerged when soil moisture levels were low at planting compared with $18 \%$ emergence in years with adequate soil moisture. What is unclear is the amount of moisture that is considered appropriate for pennycress production. It is well established that pennycress is susceptible to moisture stress (Anderson and Best 1965; Hazebroek and Metzger 1990a; Royo-Esnal et al. 2015); however, prior studies have merely used "adequate" to quantify the amount of moisture

Table 1 Outline of study planting information

\begin{tabular}{|c|c|c|c|c|c|c|c|}
\hline Study & $\begin{array}{l}\text { Location } \\
\text { (USA unless noted) }\end{array}$ & $\begin{array}{l}\text { Treatment } \\
\text { investigated }\end{array}$ & $\begin{array}{l}\text { Seeding rate } \\
\mathrm{kg} \mathrm{ha}^{-1}\end{array}$ & $\begin{array}{l}\text { Planting } \\
\text { method }\end{array}$ & $\begin{array}{l}\text { Spacing } \\
\mathrm{cm}\end{array}$ & $\begin{array}{l}\text { Seeding depth } \\
\mathrm{cm}\end{array}$ & $\begin{array}{l}\text { Fertilization } \\
\mathrm{kg} \mathrm{ha}^{-1} \text { N-P-K }\end{array}$ \\
\hline Dose et al. 2017 & Swan Lake, MN & Planting date & 6.7 & Drilled & 20 & 0.6 & $90-34-34$ \\
\hline Eberle et al. 2015 & $\begin{array}{l}\text { - Swan Lake, MN } \\
\text { - Elkton, SD }\end{array}$ & $\begin{array}{l}\text { Pollinator } \\
\text { preference }\end{array}$ & 6.7 & $\begin{array}{l}\text { - Drilled } \\
\text { - Frost seeded }\end{array}$ & 19 & • 1.3 & $90-34-34$ \\
\hline Gesch et al. 2016 & $\begin{array}{l}\text { Swan Lake, MN; } \\
\text { Teruel, Spain }\end{array}$ & $\begin{array}{l}\text { Effect of seed } \\
\text { position }\end{array}$ & $11.6^{*}$ & Not reported & 25 & 1.0 & Not reported \\
\hline $\begin{array}{l}\text { Groeneveld and } \\
\text { Klein } 2014\end{array}$ & $\begin{array}{l}\text { Dundenheim, } \\
\text { Germany }\end{array}$ & $\begin{array}{l}\text { Pollinator } \\
\text { preference }\end{array}$ & $3.0-5.0$ & Broadcasted & --- & --- & Not fertilized \\
\hline Carr 1993 & Guptill, ND & Yield & Not reported & Broadcasted & --- & --- & Not reported \\
\hline $\begin{array}{l}\text { Johnson et al. } \\
2015 \\
\text { Experiment } 1\end{array}$ & $\begin{array}{l}\text { Lamberton, MN; } \\
\text { Rosemount, MN; } \\
\text { Waseca, MN }\end{array}$ & $\begin{array}{l}\text { Companion } \\
\text { crop, location, } \\
\text { seeding rate }\end{array}$ & $5.5,11.0$ & Drilled & 25 & Not reported & Not reported \\
\hline $\begin{array}{l}\text { Johnson et al. } \\
2015 \\
\text { Experiment } 2\end{array}$ & $\begin{array}{l}\text { Lamberton, MN; } \\
\text { Rosemount, MN; } \\
\text { Wasecea, MN }\end{array}$ & $\begin{array}{l}\text { Companion } \\
\text { crop, location, } \\
\text { seeding date, } \\
\text { seeding rate, } \\
\text { variety }\end{array}$ & $5.5,11.0$ & Drilled & 25 & Not reported & Not reported \\
\hline $\begin{array}{l}\text { Johnson et al. } \\
2017\end{array}$ & $\begin{array}{l}\text { Rosemount, MN; } \\
\text { Saint Paul, MN; } \\
\text { Waseca, MN }\end{array}$ & $\begin{array}{l}\text { Cropping } \\
\text { system, harvest } \\
\text { time }\end{array}$ & 16.8 & Drilled & 10 & Not reported & Not reported \\
\hline $\begin{array}{l}\text { Phippen et al. } \\
\text { 2010a }\end{array}$ & Macomb, IL & $\begin{array}{l}\text { Planting method, } \\
\text { seeding rate }\end{array}$ & $1.1,2.2,4.9$ & $\begin{array}{l}\text { - Broadcasted } \\
\text { - Drilled }\end{array}$ & $\bullet---$ & $\bullet---$ & Not reported \\
\hline $\begin{array}{l}\text { Phippen et al. } \\
2010 \mathrm{~b}\end{array}$ & Macomb, IL & $\begin{array}{l}\text { Herbicide, } \\
\text { planting date }\end{array}$ & Not reported & Drilled & 7.5 & Not reported & Not reported \\
\hline $\begin{array}{l}\text { Phippen and } \\
\text { Phippen } 2012\end{array}$ & Macomb, IL & Double-crop & 6.7 & Drilled & 19 & Not reported & Not fertilized \\
\hline $\begin{array}{l}\text { Rukavina et al. } \\
2011\end{array}$ & Macomb, IL & Fertilization & 4.5 & Not reported & --- & --- & $\begin{array}{l}0,28,56,84 \\
112 \mathrm{~N} ; 11 \mathrm{~S}\end{array}$ \\
\hline $\begin{array}{l}\text { Groeneveld and } \\
\text { Klein } 2015\end{array}$ & Oßweil, Germany & Insect diversity & 22 & Not reported & --- & --- & $\begin{array}{l}\text { Cattle manure, } \\
\text { unknown }\end{array}$ \\
\hline $\begin{array}{l}\text { Groeneveld et al. } \\
2015\end{array}$ & Oßweil, Germany & Insect diversity & 22 & Not reported & --- & --- & $\begin{array}{l}\text { Cattle manure, } \\
\text { unknown }\end{array}$ \\
\hline
\end{tabular}

*Average 1000-seed weight for seeds at harvest maturity from Cubins (2019), unpublished, used to extrapolate planting rate 
available (Zanetti et al. 2013; Royo-Esnal et al. 2015). Determining the threshold of adequate versus inadequate moisture for pennycress development may warrant further research. In comparison to sympatric species such as wild oat (Avena fatua) and wheat, pennycress has low water use efficiency (Anderson and Best 1965), requiring $405 \mathrm{~kg}$ of water to produce $0.45 \mathrm{~kg}$ of dry matter (Hazebroek and Metzger 1990a). Depressed yields are directly associated with limited water availability as low moisture levels can decrease the likelihood of branching, which allows pennycress to compensate for low stand density (Matthies 1990), and may reduce pennycress vertical growth to only $1.25 \%$ of its potential height (Best and McIntyre 1975). In general, pennycress is not well adapted for arid environments where natural precipitation is the only form of moisture (Royo-Esnal et al. 2017). Johnson et al. (2017) remedied issues associated with limited moisture by watering pennycress plots with $25 \mathrm{~mm}$ of water to promote germination. Another study conducted in Montana showed that, when supplemental irrigation was provided, pennycress yielded $1684 \mathrm{~kg} \mathrm{ha}^{-1}$ (Clopton and Triebold 1944). Alternatively, higher planting rates can be used to compensate for potentially lower germination rates during dry conditions (Johnson et al. 2015; Zanetti et al. 2018), but may not be a reliable way to meet yield goals. In the future, breeding efforts will be necessary to develop pennycress varieties suitable for dryland regions. While pennycress seeding method and seeding depth has been established, optimal seeding rate over a variety of climatic conditions has not been well developed and requires future research.

\subsection{Fertilization requirements}

Few studies have been conducted concerning the direct fertilization needs of pennycress. Ongoing experiments with pennycress within the corn-soybean rotation suggest that no fertilizer application may be necessary for successful production due to residual nutrients applied during the summer annual portion of the system. Yield response due to the application of nitrogen and sulfur fertilizers on pennycress seed yield and oil content was quantified by Rukavina et al. (2011). This study, conducted in western Illinois, indicated that a fall application of $112 \mathrm{~kg} \mathrm{ha}^{-1} \mathrm{~N}$ produced the maximum seed yield of $995 \mathrm{~kg} \mathrm{ha}^{-1}$, but did not significantly outperform treatments with lower fertilizer rates. This indicates that maximum yields may be achieved with fewer resources. The lowest $\mathrm{N}$ application rate that maintained top pennycress yield required a split application of $28 \mathrm{~kg} \mathrm{ha}^{-1}$ applied in both the fall and spring (Rukavina et al. 2011). Recent studies in Minnesota have utilized a spring application of 90,34 , and $34 \mathrm{~kg} \mathrm{ha}^{-1}$ of N, P, and $\mathrm{K}$, respectively, following spring thaw before pennycress reproductive development began (Eberle et al. 2015; Dose et al. 2017). However, the benefits of fertilization were not quantified. There is also a risk of plant lodging due to over- fertilization when pennycress is exposed to extreme weather events (i.e., heavy winds or excessive precipitation) after plants have elongated during reproductive development (personal observation). Overall, there is no clear fertilization strategy to optimize pennycress production and more research is needed on this component of the pennycress production system.

\section{Harvest}

Current pennycress lines are prone to shatter, which increases susceptibility to seed loss at harvest when plants are at low moisture content (Best and McIntyre 1975; Sedbrook et al. 2014; Dorn et al. 2015). This loss can be caused by environmental disturbances, such as high wind or precipitation, or by cultural disturbances, such as equipment for harvest or the planting of a subsequent relay crop, and has been noted in related Brassicaceae species (Vera et al. 2007; Sintim et al. 2016). Loss due to shattering directly corresponds to pennycress yield reduction at harvest and can significantly contribute to the weed seed bank as a single plant can shed between 1600 and 15000 seeds (Best and McIntyre 1975). Carlson (2018) found that seed loss due to shattering was equivalent to 300 times the initial seeding rate. While silicle shatter is an undesirable trait for agricultural production, it is important to remember that the studies reviewed in this paper largely utilize wild accessions of pennycress (Phippen and Phippen 2013; Johnson et al. 2015, 2017; Royo-Esnal et al. 2017; Carlson 2018; Ott 2018; Zanetti et al. 2018; Cubins 2019; Ott et al. 2019), which retain many weedy characteristics (Frels et al. 2017; Zanetti et al. 2018; Altendorf et al. 2019) that are beneficial for natural propagation (Warwick et al. 2002). Pennycress seed is viable as early as 6 days after anthesis (Hume 1984), may not experience any dormancy when produced under warm conditions (Hume 1994), and can persist in the weed seed bank for decades (Croker 1938; Kjaer 1948). As shattered seed germinates, pennycress seedlings may directly compete with crops that follow, such as canola, wheat, and safflower (Carthamus tinctorius) (Warwick et al. 2002). However, pennycress susceptibility to herbicide chemistries (Andersson 1994) such as glyphosate and glufosinate (Sedbrook et al. 2014) as well as suspected susceptibility to 2,4-dichlorophenoxyacetic acid, imazethapyr, and acifluorfen will likely decrease its competitive ability if a pre-emergent herbicide is used (Sindelar et al. 2017).

Despite these production challenges, it is largely agreed that pennycress is a good candidate for mechanical harvest (Clopton and Triebold 1944; Eberle et al. 2015; Dose et al. 2017) even though mechanical harvest is the most efficient when seeds are dry and silicles are prone to shatter. One strategy for reducing shattering loss is to harvest pennycress at physiological maturity. Pennycress physiological maturity 
occurred nearly 2 weeks prior to typical harvest periods, i.e., harvest maturity (Fig. 3), when seed moisture was low enough for effective mechanical harvest (Cubins 2019). Delaying harvest until typical harvest periods resulted in a $70 \%$ loss in seed yield compared with harvesting at physiological maturity, i.e., maximum yield potential. Consequently, Cubins (2019) proposed the use of a harvest aid at physiological maturity to dry pennycress to a point that facilitates efficient mechanical harvest. The majority of agronomic studies reviewed were harvested by hand (Table 1), which does not require seeds to have reached full maturity by the time of harvest. In some studies, however, paraquat dichloride (1'dimethyl-4,4'-bipyridinium dichloride) was applied to assist plant drying prior to combining (Eberle et al. 2015; Dose et al. 2017) and may be used as a desiccant in the future to decrease the time between physiological maturity and harvest maturity. Harvest timing spanned mid-May through mid-July at all reviewed study locations. Studies that were conducted in Illinois were more likely to be harvested in late May or early June (Phippen et al. 2010b; Rukavina et al. 2011; Phippen and Phippen 2012) as opposed to studies in western Minnesota and North Dakota, which were harvested between late June and early July (Carr 1993; Eberle et al. 2015; Gesch et al. 2016; Dose et al. 2017; Cubins 2019). Different growing conditions (e.g., length of winter

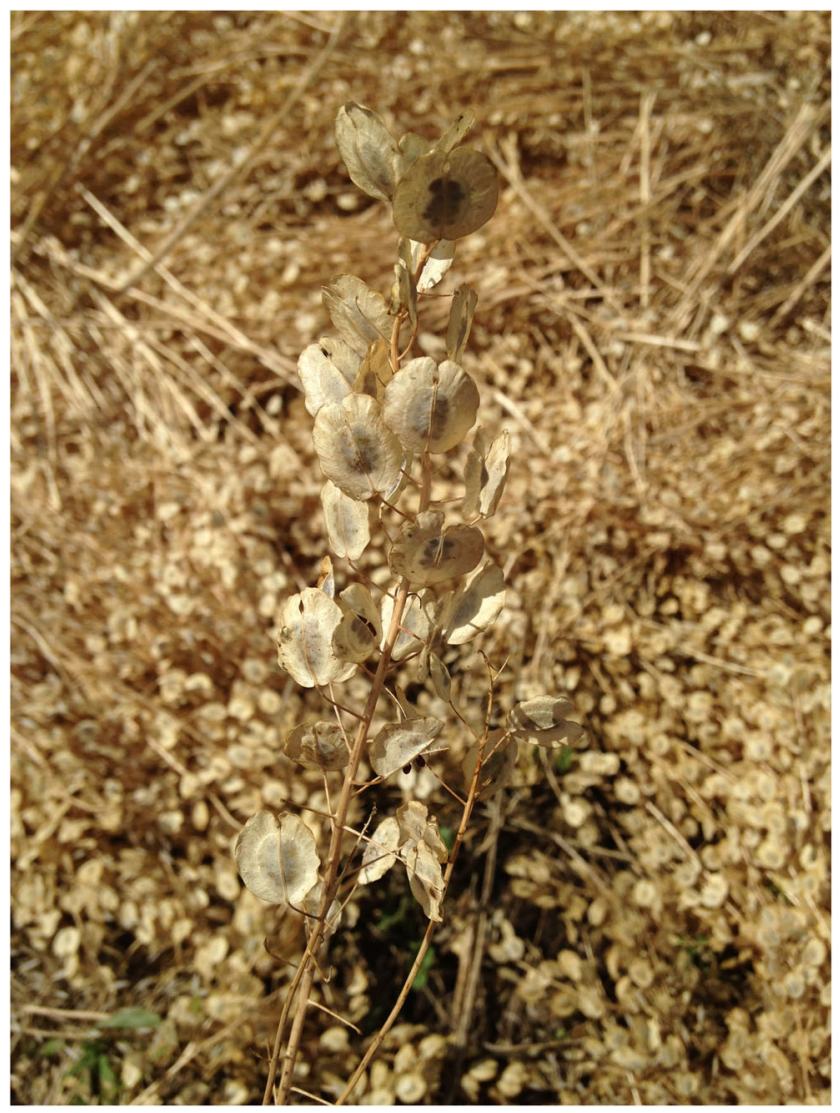

Fig. 3 Pennycress at harvest maturity when plant and seed moisture have reached adequate levels (12-15\%) for effective mechanical harvest. Photo by Sarah Moore and amount of precipitation) are highly influential in determining when pennycress reaches maturity and can be harvested. Loss of seed at low moisture content in pennycress has been well documented, and strategies to reduce moisture content using a harvest aid when seed reaches physiological maturity should be the focus of future research.

\subsection{Seed yield}

The primary product of pennycress production is oil (Moser et al. 2009a; Moser 2012), and oil production can be optimized by simultaneously maximizing seed yield and seed oil content. One estimate suggests that pennycress yields need to reach $1684 \mathrm{~kg} \mathrm{ha}^{-1}$ to offset production costs (J. Sedbrook, personal communication, 8 May 2018). While pennycress has the potential for prolific yields, studies of natural accessions have demonstrated a high degree of yield variability. It should be noted that there is a lack of published material pertaining to pennycress yield outside the Upper Midwest, so yield information is restricted to the USA. Of the studies considered in this review (Table 2), only two had yields that exceeded the proposed threshold of profitability and each had treatments that yielded far lower values (Carr 1993; Johnson et al. 2017). Average yields of the studies reviewed were greatest in Illinois, the southern-most state, followed by Minnesota and South Dakota (Fig. 4). Yields in Illinois had a greater standard deviation than those in Minnesota, which may be partially due to that fact that fewer field studies have been conducted in Illinois as opposed to Minnesota (Fig. 4; Table 2). While there are many factors that contribute to variability in pennycress seed yield, stand density and environment are the primary constraints. A high degree of phenotypic plasticity (Susko and Cavers 2008) in pennycress can partially compensate for low stand density by increasing the seed yield of individual plants in response to decreased population density (Matthies 1990). Due to the branching morphology of pennycress, yields across planting rates were similar to each other even at half or a quarter of the maximum seeding rate of $4.9 \mathrm{~kg} \mathrm{ha}^{-1}$ (Phippen et al. 2010a). Another example this plasticity occurs with spring versus fall germinated seed. Seedlings that germinate in the spring are more likely to grow taller, branch more, and produce a greater amount of small seed than fall-germinated pennycress (Hume 1990). While relying on natural branching may be a good strategy in years with unexpected stand loss, planting at a higher seeding rate is considered a more reliable method of increasing stand uniformity and reducing the risk of low yield due to poor germination (Johnson et al. 2015). Overall, there is consensus that pennycress yield is highly dependent on in-season environmental factors (Johnson et al. 2017), which further complicates the design of pennycress best management practices. Yields in one study reflected rainfall patterns because germination was highly dependent on soil moisture (Johnson et al. 
Table 2 Outline of study harvest information

\begin{tabular}{|c|c|c|c|c|c|c|c|}
\hline Study & $\begin{array}{l}\text { Location } \\
\text { (USA unless noted) }\end{array}$ & $\begin{array}{l}\text { Treatment } \\
\text { investigated }\end{array}$ & $\begin{array}{l}\text { Harvest } \\
\text { method }\end{array}$ & $\begin{array}{l}\text { Minimum } \\
\text { yield } \mathrm{kg} \mathrm{ha}^{-1}\end{array}$ & $\begin{array}{l}\text { Maximum } \\
\text { yield } \mathrm{kg} \mathrm{ha}^{-1}\end{array}$ & $\begin{array}{l}\text { Minimum } \\
\text { oil content } \%\end{array}$ & $\begin{array}{l}\text { Maximum } \\
\text { oil content \% }\end{array}$ \\
\hline Dose et al. 2017 & Swan Lake, MN & Planting date & Plot combine & 200 & 1100 & 34 & 36 \\
\hline Eberle et al. 2015 & $\begin{array}{l}\text { - Swan Lake, MN } \\
\text { - Elkton, SD }\end{array}$ & $\begin{array}{l}\text { Pollinator } \\
\text { preference }\end{array}$ & $\begin{array}{l}\text { - Plot combine } \\
\text { - Hand harvest }\end{array}$ & $\begin{array}{l}\cdot 230 \\
\cdot 0\end{array}$ & $\begin{array}{l}\cdot 1110 \\
\cdot 520\end{array}$ & Not reported & Not reported \\
\hline Gesch et al. 2016 & $\begin{array}{l}\text { - Swan Lake, MN } \\
\text { - Teruel, Spain }\end{array}$ & Effect of seed position & Hand harvest & Not reported & Not reported & $\begin{array}{l}\cdot 32 \\
\cdot 26\end{array}$ & $\begin{array}{l}\cdot 33 \\
\cdot 31\end{array}$ \\
\hline Carr 1993 & Guptill, ND & Yield & Hand harvest & 119 & 1628 & 26 & 26 \\
\hline $\begin{array}{l}\text { Johnson et al. } 2015 \\
\text { Experiment } 1\end{array}$ & $\begin{array}{l}\cdot \text { Lamberton, MN } \\
\text { - Rosemount, MN } \\
\text { - Waseca, MN }\end{array}$ & $\begin{array}{l}\text { - Companion crop } \\
\text { - Seeding rate } \\
\text { - Companion crop, } \\
\text { seeding rate } \\
\text { - Companion crop } \\
\text { - Seeding rate }\end{array}$ & Hand harvest & $\begin{array}{l}\cdot 104 \\
\cdot 161 \\
\cdot 477 \\
\cdot 390 \\
\cdot 672\end{array}$ & $\begin{array}{l}\cdot 113 \\
\cdot 168 \\
\cdot 1387 \\
\cdot 513 \\
\cdot 694\end{array}$ & Not reported & Not reported \\
\hline $\begin{array}{l}\text { Johnson et al. } 2015 \\
\text { Experiment } 2\end{array}$ & $\begin{array}{c}\text { - Rosemount, MN } \\
(2010 / 2011) \\
\cdot \text { Rosemount, } \\
\text { MN (2012) }\end{array}$ & $\begin{array}{l}\text { - Companion crop } \\
\text { - Seeding date } \\
\text { - Companion crop } \\
\text { - Seeding date } \\
\text { - Variety }\end{array}$ & Hand harvest & $\begin{array}{l}\cdot 133 \\
\cdot 116 \\
\cdot 441 \\
\cdot 441 \\
\cdot 796\end{array}$ & $\begin{array}{l}\cdot 270 \\
\cdot 204 \\
\cdot 1129 \\
\cdot 1245 \\
\cdot 1245\end{array}$ & Not reported & Not reported \\
\hline Johnson et al. 2017 & $\begin{array}{l}\text { - Rosemount, MN } \\
\text { - Saint Paul, MN } \\
\text { - Waseca, MN }\end{array}$ & $\begin{array}{l}\text { Cropping system, } \\
\text { harvest time }\end{array}$ & Hand harvest & $\begin{array}{l}\cdot 500 \\
\cdot 1450 \\
\cdot 75\end{array}$ & $\begin{array}{l}\cdot 1000 \\
\cdot 2400 \\
\cdot 1200\end{array}$ & Not reported & Not reported \\
\hline Phippen et al. 2010a & Macomb, IL & $\begin{array}{l}\text { Planting method, } \\
\text { seeding rate }\end{array}$ & Hand harvest & 345 & 535 & 28 & 29 \\
\hline Phippen et al. 2010b & Macomb, IL & $\begin{array}{l}\cdot \text { Herbicide } \\
\text { - Planting date }\end{array}$ & Hand harvest & $\begin{array}{l}\cdot 150 \\
\cdot \text { Not } \\
\text { reported }\end{array}$ & $\begin{array}{l}\cdot 1120 \\
\cdot \text { Not } \\
\text { reported }\end{array}$ & $\begin{array}{l}\cdot 30 \\
\cdot 30\end{array}$ & $\begin{array}{l}\cdot 34 \\
\cdot 36\end{array}$ \\
\hline $\begin{array}{l}\text { Phippen and } \\
\text { Phippen } 2012\end{array}$ & Macomb, IL & Double-crop & Not reported & 672 & 896 & Not reported & Not reported \\
\hline Rukavina et al. 2011 & Macomb, IL & Fertilization & Hand harvest & 351 & 1117 & 34 & 36 \\
\hline
\end{tabular}

2015). Dose et al. (2017) presented contrary evidence to this finding, suggesting that pennycress yield was not correlated to seasonal variables such as precipitation, soil temperature at planting, or cumulative photohydrothermal time, but was

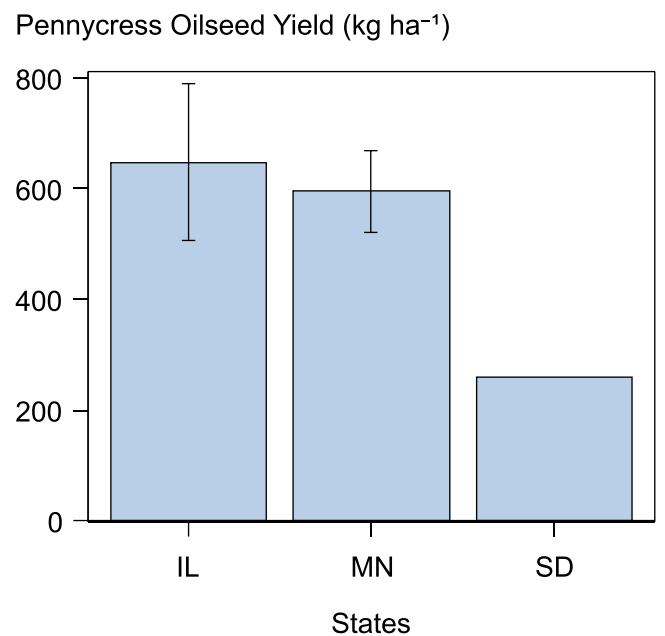

Fig. 4 Differences between pennycress oilseed yield $\left(\mathrm{kg} \mathrm{ha}^{-1}\right)$ by state in the Upper Midwest most reflective of air temperature at planting in which earlier planting dates corresponded with higher yields. There is a high degree of yield variability in current lines of pennycress. Much of this corresponds to environmental influence but may be reduced by planting at higher seeding rates to increase stand uniformity.

\section{Seed oil content and quality}

Pennycress seed oil content ranges between 26 and 39\% (Carr 1993; Phippen et al. 2010a; Rukavina et al. 2011; Gesch et al. 2016; Dose et al. 2017), and this high oil content makes it a good candidate for biodiesel production (Clopton and Triebold 1944; Phippen and Phippen 2013; Isbell et al. 2015b; Royo-Esnal et al. 2017). A range of seed oil content from recent agronomic studies can be found in Table 2 . Similar to seed yield, environmental factors, such as soil temperature and precipitation, can significantly influence seed oil content. Dose et al. (2017) found that low soil temperatures accounted for $63 \%$ of the variation in seed oil 
content of fall-planted pennycress. When pennycress was planted at soil temperatures below $5^{\circ} \mathrm{C}$ (i.e., November planting date), seed oil content ranged between 26 and 30\%, whereas when pennycress was planted at soil temperatures of $30{ }^{\circ} \mathrm{C}$ (i.e., late August planting date), seed contained around 36\% oil. By planting earlier, pennycress had a longer maturation period, which favored high oil content (Dose et al., 2017); however, lower erucic acid levels were associated with later planting dates (Phippen et al. 2010b), which may be due to a shorter growth period. Precipitation also has significant influence on seed oil content. A year with $253 \mathrm{~mm}$ versus $406 \mathrm{~mm}$ of precipitation yielded seed with $26 \%$ and $36 \%$ oil, respectively, and variation in precipitation accounted for $86 \%$ of the variation in oil content (Dose et al. 2017). Overall, seed oil content was stable across drilled and broadcasted planting methods and was not shown to be as variable as yield over planting method and varying seeding rates (Phippen et al. 2010a). Seed oil content has been relatively stable across research studies and methods but still experiences variation due to environmental factors.

Pennycress oil is mainly comprised of components of the oleic acid (18:1) biosynthetic pathway: linoleic (18:2), linolenic (18:3), eicosenoic (20:1), and erucic (22:1) acids (Sedbrook et al. 2014). Of these products, erucic acid accounts for the majority of seed oil content and reported values have consistently ranged between 29 and 36\% (Isbell 2009; Moser et al. 2009b; Cermak et al. 2013; Phippen and Phippen 2013; Zanetti et al. 2018). The remaining fatty acids have yielded similarly across accessions and study locations with oleic, linoleic, linolenic, and eicosenoic acids comprising around $11 \%, 20 \%, 13 \%$, and $10 \%$, respectively, of the total fatty acid content (Evangelista et al. 2017; Zanetti et al. 2018; Altendorf et al. 2019; Cubins 2019). Due to this composition, pennycress oil is a candidate to be used as an industrial lubricant (Cermak et al. 2015) due to its high viscosity and cold flow properties (Fan et al. 2013; Cermak et al. 2015; Evangelista et al. 2017). For these reasons, pennycress is also a candidate to increase domestic fuel production for the aviation industry (Sindelar et al. 2017). When compared with other oilseed crops, pennycress would need to produce between 561 and $1123 \mathrm{~kg} \mathrm{ha}^{-1}$ of oil to directly compete with markets for rapeseed oil due to similar oil properties (Clopton and Triebold 1944). More recently, established extrusion procedures have yielded 600 to $1200 \mathrm{~L}$ of pennycress oil per hectare (Moser et al. 2009a), which is equivalent to 540 to $1080 \mathrm{~kg} \mathrm{ha}^{-1}$ (Noureddini et al. 1992).

\section{Cropping strategies}

The aforementioned oil characteristics can be leveraged by including pennycress in an integrated cropping system such as a double- or relay crop (Clopton and Triebold 1944; Carr
1993; Heaton et al. 2013; Sindelar et al. 2017; Bishop and Nelson 2019). Due to its early summer harvest, pennycress can be double-cropped with soybean and other summer annuals without jeopardizing yield (Isbell 2009; Moser 2012; Phippen and Phippen 2012; Johnson et al. 2017). There were no differences in oil content or protein of soybeans doublecropped with pennycress when compared with soybeans grown without a fall-seeded crop (Johnson et al. 2015). Despite a slightly shorter growing season, double-cropped soybean had ample time to reach maturity before the first fall frost (Johnson et al. 2015) and soybean yields were be maintained even with the addition of pennycress (Johnson et al. 2015; Bishop and Nelson 2019). Phippen and Phippen (2012) demonstrated that, when double-cropped with soybean, pennycress had a positive effect on soybean yield in both years of the study but was only significant in the second year, further indicating the importance of annual environmental fluctuation. Only one study found that pennycress reduced soybean grain yield by $18-30 \%$ when double- or relay cropped (Johnson et al. 2017). Although there was a reduction in soybean yield, total annual grain yield was increased by 48 $102 \%$ depending on location and environment after oilseed yields (i.e., pennycress and soybean) were combined (Johnson et al. 2017). Similarly, in a relay cropping study where a full season soybean was no-till planted into standing pennycress, total annual seed yield was $79 \%$ greater than a conventionally managed soybean planted without a relay crop (Ott et al. 2019).

Despite the potential economic benefit of incorporating pennycress into a cropping rotation, risks may be incurred. Integrated systems will be most successful in areas with ample precipitation as pennycress yields may be negatively affected if competition for water is present (Clopton and Triebold 1944; Johnson et al. 2015; Royo-Esnal et al. 2017). This has the potential to negate economic benefits if oil yield is not great enough to match input costs. Due to its small seed size, pennycress had trouble germinating in high residue environments (Eberle et al. 2015; Johnson et al. 2017) indicating that planting pennycress into annual crops with a large amount of stubble or leaf litter following harvest may be unsuitable for pennycress production unless residue is removed prior to planting (personal observation). In short, pennycress can be integrated into a summer annual cropping system while increasing total annual oilseed yield; however, it is not without challenges and, in some years, the risks incurred may be greater than the profit contributed by the additional crop.

\section{Ecosystem services}

An ability to scavenge nutrients has made pennycress an attractive option as a low-input winter annual. Between 73 and $77 \%$ of annual nitrate loss in the corn-soybean rotation occurs 
between April and June (Randall and Vetsch 2005), which suggests excess soil nitrogen availability to support a winter annual crop. Pennycress had 18 to $19 \%$ less nitrogen in the soil profile down to $60 \mathrm{~cm}$ in the fall compared with a fallow plot and 53 to $72 \%$ less nitrogen in the spring after oilseed harvest and before soybean planting (Johnson et al. 2017). Similarly, soybean relay cropped with pennycress sequestered between 35 and $40 \mathrm{~kg} \mathrm{ha}^{-1}$ of nitrogen by mid-spring, which was comparable to a crop of winter rye (Secale cereale) (Ott et al. 2019). This corresponded to a $20 \mathrm{~kg} \mathrm{ha}^{-1}$ reduction in soil nitrate levels when directly compared with a fallow tilled control (Ott 2018) and indicates that pennycress is efficiently able to remove nitrogen from the soil profile.

Pennycress can be utilized as part of a comprehensive integrated weed management strategy (Vaughn et al. 2005; Johnson et al. 2015). Fall establishment can provide early spring ground cover and suppress aggressive springgerminating weeds such as common lambsquarters (Chenopodium album), giant ragweed (Ambrosia trifida), and tall waterhemp (Amaranthus tuberculatus) (Johnson et al. 2015). Johnson et al. (2015) speculated that weed suppression may have been caused by allelopathic compounds rather than ground cover when pennycress seeding rates and companion crops were taken into account. The majority of weed suppression research has focused on the use of the sinigrin components allyl isothiocyanate and allyl thiocyanate in pennycress seed meal to suppress weed seed germination (Vaughn et al. 2005, 2006; Isbell 2009). Pennycress seed meal can provide $100 \%$ suppression of weed seeds when incorporated into the soil at $1 \%(\mathrm{wt} / \mathrm{wt}$ ) (Isbell 2009). Similarly, pennycress seed meal was able to suppress the germination of both sicklepod (Senna obtusifolia) and velvetleaf (Abutilon theophrasti) at allyl isothiocyanate and allyl thiocyanate concentrations of $5 \mathrm{ppm}$, and provided over $90 \%$ control of weeds in both tarped and untarped field conditions (Vaughn et al. 2005). While acting as an effective weed control, what remains unclear is whether these compounds stay active in the soil and pose risks to intentionally seeded crops if they are planted too soon after pennycress harvest or residue incorporation. Allyl isothiocyanate and allyl thiocyanate were found to suppress the germination of wheat, annual ryegrass (Lolium multiflorum), and arugula (Eruca vesicaria ssp. sativa) at 1, 1, and $5 \mathrm{ppm}$, respectively (Vaughn et al. 2005). It is interesting to note that the germination of arugula, a fellow Brassicaceae, was less affected by pennycress seed meal application than wheat and annual ryegrass (Vaughn et al. 2005), indicating that pennycress volatiles may not be as effective at controlling the germination of other Brassicaceae crops. Another study found that wheat germination was inhibited by pennycress seed meal at levels as low as $0.1 \%$ (Vaughn et al. 2006).

There is also potential for pennycress to be an integral part of an effective and sustainable integrated pest management strategy. Pennycress increased biocontrol potential and provided habitat for spiders, a generalist predator (Groeneveld et al. 2015). Spider abundance was not affected by pennycress growth in a corn-pennycress system, and spider species richness and diversity increased when compared with three common corn crop rotations, as characterized by the Shannon index (Groeneveld et al. 2015). The addition of pennycress to a corn rotation also increased and stabilized ground beetle diversity more effectively than a mustard (Sinapis alba)-corn rotation, a green fallow-corn rotation, or a bare fallow-corn rotation (Groeneveld and Klein 2015). This was mainly due to the evenness of plant cover throughout the growing season.

Pollinators can also benefit from pennycress's early flowering time. Forage is scarce in the early spring when most plants on the landscape have not germinated or bloomed, but pennycress can help to fill this gap (Evangelista et al. 2017). In 1 year of study, pennycress produced only $13 \mathrm{~kg} \mathrm{ha}^{-1}$ of nectar in comparison with camelina and canola, which produced 100 and $83 \mathrm{~kg} \mathrm{ha}^{-1}$ of nectar, respectively (Eberle et al. 2015). While pennycress produces less nectar than other angiosperms, as many as 68 insects per minute visited its flowers, indicating that pennycress may provide other resources to pollinators such as pollen. Indeed, pennycress produced $38 \mathrm{~kg}$ $\mathrm{ha}^{-1}$ of pollen compared with 58 and $109 \mathrm{~kg} \mathrm{ha}^{-1}$ by camelina and canola (Thom et al. 2018). Recorded visitors mainly consisted of flies, but an earlier flowering period over 1 year of the study lead to a $200 \%$ increase in the number of small bees visiting, potentially due to a lack of other flowering resources on the landscape. Research conducted in Germany concluded similarly that the majority of flower visitors were flies, but also noted a number of bee visitors (Groeneveld and Klein 2014). Pennycress provides services that are imperative to a sustainable ecosystem, and the integration of this crop can reduce nutrient leaching, decrease pest pressure, and increase the population of beneficial organisms.

\section{Germplasm development}

Pennycress has excellent potential for rapid domestication and genetic improvement (DeHaan et al. 2016). The advantages of pennycress include a small diploid genome, self-fertility, a rapid lifecycle, and a close genetic relationship with the well-studied Brassicaceae species Arabidopsis thaliana and canola (Sharma et al. 2007; Sedbrook et al. 2014; Dorn et al. 2015). The small genome size allowed rapid development of a pennycress transcriptome and draft genome that are being used to identify key genes for domestication (Dorn et al. 2013, 2015). Wild collections (accessions) of pennycress have been made throughout the USA, Canada, and Europe for the purpose of developing breeding programs. Some of these accessions are maintained at the USDA North Central Regional Plant Introduction Station in Ames, IA. Accessions are also 
maintained at Western Illinois University and at the University of Minnesota, and have been screened for agronomic and oilquality/end use traits (Sedbrook et al. 2014; Altendorf et al. 2019). Phenotypic variation for maturity, yield components, and seed dormancy have been identified in wild pennycress accessions (Isbell et al. 2015a, 2017; Altendorf et al. 2019); however, significant variations for traits such as silicle shatter, erucic acid content, and sinigrin content were not identified. A recent evaluation of genetic diversity showed that the genetic variation present in North American pennycress accessions was limited (Frels et al. 2017). Therefore, alternative tools such as chemical mutagenesis and gene editing have been used to create genetic variation for key domestication traits (Chopra et al. 2018, 2019a; McGinn et al. 2018).

Wild pennycress carries three traits that limit commercialization for multiple end uses: silicle shatter at low moisture content, oil with high erucic acid content, and sinigrin content in the meal remaining after pressing (Sedbrook et al. 2014). In order to develop pennycress for profitable end uses, including human and animal food uses, the germplasm must be improved to reduce these undesirable traits. The reduction in erucic acid and sinigrin content has largely followed the steps laid out by researchers who developed canola from rapeseed (Bell 1982; Claver et al. 2017). Recently, pennycress lines with reduced erucic acid content and increased oleic, linoleic, and linolenic acid content were identified through the use of both chemical mutagenesis and CRISPR-Cas9 gene editing (McGinn et al. 2018; Chopra et al. 2019b). In addition, pennycress lines with reduced sinigrin and silicle shatter were identified (Chopra et al. 2019b). Stacking the reduced erucic content, sinigrin content, and silicle shatter traits together will result in pennycress lines with edible oil and meal and improved harvestability. Further combining these traits into elite breeding lines selected for improved germination, early maturity, and increased yield will ease the adoption of pennycress as a cash cover crop.

\section{Conclusion}

Few studies have tackled questions pertaining to pennycress best management practices, and many questions remain unanswered. Techniques used in pennycress agronomic research vary greatly among researchers and requires clarification. The time of seeding and seeding method are established parameters, but seeding rate and row spacing warrant further evaluation to optimize plant density in both arid and precipitous conditions. Nutrient recommendations are very preliminary, and pennycress baseline requirements must be quantified. Using this information, researchers will be able to determine whether pennycress requires nutrient input or if its scavenging ability is sufficient without additional fertilization. Techniques to reduce pennycress shatter loss at harvest will also be necessary in ensuring maximum profitability, and breeding strategies have been implemented to develop nonshatter lines for future use (Dorn et al. 2015). Until more shatter-resistant cultivars are available for production, refined harvest management strategies are necessary to reduce pennycress moisture to facilitate the earliest harvest after physiological maturity occurs. This will allow pennycress to be mechanically harvested on a field scale and double-cropped with corn, soybean, or other summer annuals. Future studies outlining economically important pests (i.e., weeds, insects, nematodes, and diseases) also need to be conducted. Attention to pennycress as a cash cover crop is relatively recent, and additional research is required to determine best management practices before large-scale adoption can occur.

Acknowledgments The authors would like to thank Dr. Ratan Chopra for reviewing and commenting on this manuscript. The authors would also like to thank Rebekah J. Carlson for the use of her photograph in Fig. 2 and Sarah Moore for the use of her photograph in Fig. 3.

\section{Compliance with ethical standards}

Conflict of interest The authors declare that they have no conflict of interest.

Open Access This article is distributed under the terms of the Creative Commons Attribution 4.0 International License (http:// creativecommons.org/licenses/by/4.0/), which permits unrestricted use, distribution, and reproduction in any medium, provided you give appropriate credit to the original author(s) and the source, provide a link to the Creative Commons license, and indicate if changes were made.

\section{References}

Altendorf K, Isbell T, Wyse DL, Anderson JA (2019) Significant variation for seed oil content, fatty acid profile, and seed weight in natural populations of field pennycress (Thlaspi arvense L.). Ind Crops Prod 129:261-268. https://doi.org/10.1016/j.indcrop.2018.11.054

Anderson C, Best K (1965) Water use efficiency of barley and weeds grown in the greenhouse. Soil Horizons 6:15-16

Andersson L (1994) Effects of MCPA and tribenuron-methyl on seed production and seed size of annual weeds. Swedish J Agric 24:49-56

Bell JM (1982) From rapeseed to canola: a brief history of research for superior meal and edible oil. Poult Sci 61:613-622. https://doi.org/ $10.3382 /$ ps.0610613

Best KF, McIntyre GI (1975) The biology of Canadian weeds. 9. Thlaspi arvense L. Can J Plant Sci 55:279-292

Bishop L, Nelson KA (2019) Field pennycress seeding date and corn herbicide management effects on corn, pennycress, and soybean production. Agron J 111:257-263. https://doi.org/10.2134/ agronj2018.03.0156

Carlson RJ (2018) Continuous living cover in a corn-soybean rotation: management approaches and environmental benefits. University of Minnesota, Master's thesis

Carr PM (1993) Potential of fanweed and other weeds as novel industrial oilseed crops. In: Janick J, Simon JE (eds) New Crops. Wiley, New York, pp 384-388 
Cermak SC, Biresaw G, Isbell TA, Evangelista RL, Vaughn SF, Murray R (2013) New crop oils-properties as potential lubricants. Ind Crops Prod 44:232-239. https://doi.org/10.1016/j.indcrop.2012.10.035

Cermak SC, Durham AL, Isbell TA, Evangelista RL, Murray RE (2015) Synthesis and physical properties of pennycress estolides and esters. Ind Crops Prod 67:179-184. https://doi.org/10.1016/j.indcrop.2015. 01.050

Chopra R, Johnson E, Daniels E et al (2018) Translational genomics using Arabidopsis as a model enables the characterization of pennycress genes through forward and reverse genetics. Plant J 96:10931105. https://doi.org/10.1111/tpj.14147

Chopra R, Folstad N, Lyons J, Ulmasov T, Gallaher C, Sullivan L, McGovern A, Mitacek R, Frels K, Altendorf K, Killam A, Ismail B, Anderson JA, Wyse DL, Marks MD (2019a) The adaptable use of Brassica NIRS calibration equations to identify pennycress variants to facilitate the rapid domestication of a new winter oilseed crop. Ind Crops Prod 128:55-61. https://doi.org/10.1016/j.indcrop. 2018.10.079

Chopra R, Johnson EB, Emenecker R et al (2019b) Toward the identification and stacking of domestication traits in pennycress to create a new crop. Plant $\mathrm{J}$

Claver A, Rey R, López MV, Picorel R, Alfonso M (2017) Identification of target genes and processes involved in erucic acid accumulation during seed development in the biodiesel feedstock pennycress (Thlaspi arvense L.). J Plant Physiol 208:7-16. https://doi.org/10. 1016/j.jplph.2016.10.011

Clopton JR, Triebold HO (1944) Fanweed seed oil: potential substitute for rapeseed oil. Ind Eng Chem 36:218-219. https://doi.org/10. 1021/ie50411a007

Croker W (1938) Life span of seeds. Bot Rev 4:235-274

Cubins JA (2019) Harvest time optimization of pennycress for use within the corn-soybean rotation. Master's thesis, University of Minnesota

DeHaan LR, Van Tassel DL, Anderson JA et al (2016) A pipeline strategy for grain crop domestication. Crop Sci 56:917-930. https://doi.org/ 10.2135/cropsci2015.06.0356

Dorn KM, Fankhauser JD, Wyse DL, Marks MD (2013) De novo assembly of the pennycress (Thlaspi arvense) transcriptome provides tools for the development of a winter cover crop and biodiesel feedstock. Plant J 75:1028-1038. https://doi.org/10.1111/tpj.12267

Dorn KM, Fankhauser JD, Wyse DL, Marks MD (2015) A draft genome of field pennycress (Thlaspi arvense) provides tools for the domestication of a new winter biofuel crop. DNA Res 22:121-131. https:// doi.org/10.1093/dnares/dsu045

Dose HL, Eberle CA, Forcella F, Gesch RW (2017) Early planting dates maximize winter annual field pennycress (Thlaspi arvense L.) yield and oil content. Ind Crops Prod 97:477-483. https://doi.org/10. 1016/j.indcrop.2016.12.039

Eberle CA, Thom MD, Nemec KT, Forcella F, Lundgren JG, Gesch RW, Riedell WE, Papiernik SK, Wagner A, Peterson DH, Eklund JJ (2015) Using pennycress, camelina, and canola cash cover crops to provision pollinators. Ind Crops Prod 75:20-25. https://doi.org/ 10.1016/j.indcrop.2015.06.026

Evangelista RL, Cermak SC, Hojilla-Evangelista MP et al (2017) Field pennycress: a new oilseed crop for the production of biofuels, lubricants, and high-quality proteins. In: Surfacts in Tribology, pp 369-400

Fan J, Shonnard DR, Kalnes TN, Johnsen PB, Rao S (2013) A life cycle assessment of pennycress (Thlaspi arvense L.) -derived jet fuel and diesel. Biomass and Bioenergy 55:87-100. https://doi.org/10.1016/ j.biombioe.2012.12.040

Frels K, Chopra R, Altendorf K, et al (2017) Estimating genetic diversity and population structure of founder lines in a pennycress breeding program. In: ACS Publ. https://scisoc.confex.com/crops/2017am/ webprogram/Paper106839.html. Accessed 28 Sep 2018

Gesch RW, Royo-Esnal A, Edo-Tena E, Recasens J, Isbell TA, Forcella F (2016) Growth environment but not seed position on the parent plant affect seed germination of two Thlaspi arvense L. populations. Ind Crops Prod 84:241-247. https:// doi.org/10.1016/j.indcrop.2016.02.006

Groeneveld JH, Klein AM (2014) Pollination of two oil-producing plant species: Camelina (Camelina sativa L. Crantz) and pennycress (Thlaspi arvense L.) double-cropping in Germany. GCB Bioenergy 6:242-251. https://doi.org/10.1111/gcbb.12122

Groeneveld JH, Klein AM (2015) Pennycress-corn double-cropping increases ground beetle diversity. Biomass and Bioenergy 77:16-25. https://doi.org/10.1016/j.biombioe.2015.03.018

Groeneveld JH, Lührs HP, Klein AM (2015) Pennycress double-cropping does not negatively impact spider diversity. Agric For Entomol 17: 247-257. https://doi.org/10.1111/afe.12100

Hazebroek JP, Metzger JD (1990a) Environmental control of seed germination in Thlaspi arvense (Cruciferae). Am J Bot 77:945-953. https://doi.org/10.1002/j.1537-2197.1990.tb15189.x

Hazebroek JP, Metzger JD (1990b) Seasonal pattern of seedling emergence, survival, and reproductive behavior in Thlaspi arvense (Cruciferae). Am J Bot 77:954-962

Heaton EA, Schulte LA, Berti M, Langeveld H, Zegada-Lizarazu W, Parrish D, Monti A (2013) Managing a second-generation crop portfolio through sustainable intensification: examples from the USA and the EU. Biofuels, Bioprod Biorefining 7:702-714. https://doi.org/10.1002/bbb

Holm LG, Holm L, Holm E et al (1997) World weeds: natural histories and distribution. John Wiley \& Sons, New York

Hume L (1984) The effect of seed maturity, storage on the soil surface, and burial on seeds of Thlaspi arvense L. Can J Plant Sci 64:961-969

Hume L (1990) Influence of emergence date and strain on phenology, seed production, and germination of Thlaspi arvense L. Bot Gaz 151:510-515

Hume L (1994) Maternal environment effects on plant growth and germination of two strains of Thlaspi arvense L. Int J Plant Sci 155: $180-186$

Isbell TA (2009) US effort in the development of new crops (Lesquerella, pennycress coriander and cuphea). OCL - Ol Corps Gras Lipides 16: 205-210. https://doi.org/10.1051/ocl.2009.0269

Isbell TA, Cermak SC, Dierig DA, Eller FJ, Marek LF (2015a) Registration of Katelyn Thlaspi arvense L. (pennycress) with improved nondormant traits. J Plant Regist 9:212-215. https://doi.org/ $10.3198 /$ jpr2014.08.0053crg

Isbell TA, Evangelista R, Glenn SE, Devore DA, Moser BR, Cermak SC, Rao S (2015b) Enrichment of erucic acid from pennycress (Thlaspi arvense L.) seed oil. Ind Crops Prod 66:188-193. https://doi.org/10. 1016/j.indcrop.2014.12.050

Isbell TA, Cermak SC, Marek LF (2017) Registration of Elizabeth Thlaspi arvense L. (pennycress) with improved nondormant traits. J Plant Regist 11:311-314. https://doi.org/10.3198/jpr2016.12. $0073 \mathrm{crg}$

Johnson GA, Kantar MB, Betts KJ, Wyse DL (2015) Field pennycress production and weed control in a double crop system with soybean in Minnesota. Agron J 107:532-540. https://doi.org/10.2134/ agronj14.0292

Johnson GA, Wells MS, Anderson K, Gesch RW, Forcella F, Wyse DL (2017) Yield tradeoffs and nitrogen between pennycress, camelina, and soybean in relay- and double-crop systems. Agron J 109:21282135. https://doi.org/10.2134/agronj2017.02.0065

Kjaer A (1948) Germination of buried and dry stored seeds. Proc Int Seed Test Assoc 12:167-190

Matthies D (1990) Plasticity of reproductive components at different stages of development in the annual plant Thlaspi arvense L. Oecologia 83:105-116. https://doi.org/10.1007/BF00324641

McGinn M, Bansal S, Phippen WB et al (2018) Molecular tools for advancing pennycress (Thlaspi arvense) as a new model plant and 
oilseed cash cover crop. Plant Biotechnol J. 17:776-788. https://doi. org/10.1111/pbi.13014

Milberg P, Andersson L (1994) Effect of emergence date on seed production and seed germinability in Thlaspi arvense. Swedish J Agric 24: $143-146$

Moser BR (2012) Biodiesel from alternative oilseed feedstocks: camelina and field pennycress. Biofuels 3:193-209. https://doi.org/10.4155/ bfs. 12.6

Moser BR, Knothe G, Vaughn SF, Isbell TA (2009a) Production and evaluation of biodiesel from field pennycress (Thlaspi arvense L .) Oil. Energy \& Fuels 23:4149-4155. https://doi.org/10.1016/j. indcrop.2009.03.007.(20)

Moser BR, Shah SN, Winkler-Moser JK, Vaughn SF, Evangelista RL (2009b) Composition and physical properties of cress (Lepidium sativum L.) and field pennycress (Thlaspi arvense L.) oils. Ind Crops Prod 30:199-205. https://doi.org/10.1016/ j.indcrop.2009.03.007

Noureddini H, Teoh BC, Clements LD (1992) Densities of vegetable oils and fatty acids. Chem Biomol Eng Res Publ 69:1189-1191. https:// doi.org/10.1007/BF02637678

Ott MA (2018) Four cover crops dual-cropped with soybean: agronomics, income, and nutrient uptake across Minnesota. Master's thesis, University of Minnesota

Ott MA, Eberle CA, Thom MD, Archer DW, Forcella F, Gesch RW, Wyse DL (2019) Economics and agronomics of dual-cropping pennycress and camelina with soybean in Minnesota. Agron J 111

Phippen WB, Phippen ME (2012) Soybean seed yield and quality as a response to field pennycress residue. Crop Sci 52:2767-2773. https://doi.org/10.2135/cropsci2012.03.0192

Phippen WB, Phippen ME (2013) Seed oil characteristics of wild field pennycress (Thlaspi arvense L.) populations and USDA accessions. In: West. Illinois Univ. http://www.wiu.edu/pennycress/currentexperiments/Pennycressseed-oil2013.pdf. Accessed 28 Sep 2018

Phippen W, Gallant J, Phippen M (2010a) Evaluation of planting method and seeding rates with field pennycress (Thlaspi arvense L.). In: West. Illinois Univ. http://www.wiu.edu/pennycress/currentexperiments/PlantDensity2010.pdf. Accessed 28 Sep 2018

Phippen W, John B, Phippen M, Isbell T (2010b) Planting date, herbicide, and soybean rotation studies with field pennycress (Thlaspi arvense L.). In: West. Illinois Univ. http://www.wiu.edu/pennycress/currentexperiments/PlantingDate2010.pdf. Accessed 28 Sep 2018

Randall GW, Vetsch JA (2005) Nitrate losses in subsurface drainage from a corn-soybean rotation as affected by fall and spring application of nitrogen and nitrapyrin. J Environ Qual 34:590-597. https://doi.org/ $10.2134 /$ jeq2005.0590

Royo-Esnal A, Necajeva J, Torra J, Recasens J, Gesch RW (2015) Emergence of field pennycress (Thlaspi arvense L.): Comparison of two accessions and modelling. Ind Crops Prod 66:161-169. https://doi.org/10.1016/j.indcrop.2014.12.010

Royo-Esnal A, Edo-Tena E, Torra J, Recasens J, Gesch RW (2017) Using fitness parameters to evaluate three oilseed Brassicaceae species as potential oil crops in two contrasting environments. Ind Crops Prod 95:148-155. https://doi.org/10.1016/j.indcrop.2016.10.020

Rukavina H, Sahm D, Manthey L, Phippen WB (2011) The effect of nitrogen rate on field pennycress yield and oil content. In: West.
Illinois Univ. http://www.wiu.edu/pennycress/current-experiments/ Nitrogen2011.pdf. Accessed 28 Sep 2018

Saarinen T, Lundell R, Åström H, Hänninen H (2011) Parental overwintering history affects the responses of Thlaspi arvense to warming winters in the North. Environ Exp Bot 72:409-414. https://doi.org/10.1016/j.envexpbot.2011.02.012

Sedbrook JC, Phippen WB, Marks MD (2014) New approaches to facilitate rapid domestication of a wild plant to an oilseed crop: example pennycress (Thlaspi arvense L.). Plant Sci 227:122-132. https://doi. org/10.1016/j.plantsci.2014.07.008

Sharma N, Cram D, Huebert T, Zhou N, Parkin IAP (2007) Exploiting the wild crucifer Thlaspi arvense to identify conserved and novel genes expressed during a plant's response to cold stress. Plant Mol Biol 63: 171-184. https://doi.org/10.1007/s11103-006-9080-4

Sindelar AJ, Schmer MR, Gesch RW, Forcella F, Eberle CA, Thom MD, Archer DW (2017) Winter oilseed production for biofuel in the US Corn Belt: opportunities and limitations. GCB Bioenergy 9:508524. https://doi.org/10.1111/gcbb.12297

Sintim HY, Zheljazkov VD, Obour AK, Garcia y Garcia A (2016) Managing harvest time to control pod shattering in oilseed camelina. Agron J 108:656-661. doi: https://doi.org/10.2134/ agronj2015.0300

Susko DJ, Cavers PB (2008) Seed size effects and competitive ability in Thlaspi arvense L. (Brassicaceae). Botany 86:259-267. https://doi. org/10.1139/B07-137

Thom MD, Eberle CA, Forcella F, Gesch R, Weyers S (2018) Specialty oilseed crops provide an abundant source of pollen for pollinators and beneficial insects. J Appl Entomol 142:211-222. https://doi.org/ 10.1111/jen. 12401

Vaughn SF, Isbell TA, Weisleder D, Berhow MA (2005) Biofumigant compounds released by field pennycress (Thlaspi arvense) seedmeal. J Chem Ecol 31:167-177. https://doi.org/10.1007/ s10886-005-0982-4

Vaughn SF, Palmquist DE, Duval SM, Berhow MA (2006) Herbicidal activity of glucosinolate-containing seedmeals. Weed Sci 54:743 748. https://doi.org/10.1614/WS-06-007R.1

Vera CL, Downey RK, Woods SM, Raney JP, McGregor DI, Elliott RH, Johnson EN (2007) Yield and quality of canola seed as affected by stage of maturity at swathing. Can J Plant Sci 87:13-26. https://doi. org/10.4141/P05-077

Warwick SI, Francis A, Susko DJ (2002) The biology of Canadian weeds. 9. Thlaspi arvense L. (updated). Can J Plant Sci 82:803-823. https:// doi.org/10.4141/cjps75-039

Zanetti F, Monti A, Berti MT (2013) Challenges and opportunities for new industrial oilseed crops in EU-27: A review. Ind Crops Prod 50: 580-595. https://doi.org/10.1016/j.indcrop.2013.08.030

Zanetti F, Isbell TA, Alexopoulou E et al (2018) Pennycress (Thlaspi arvense) a new non-food crop for oil-based biofuel production in Europe and USA. In: 26th European Biomass Conference and Exhibition

Publisher's note Springer Nature remains neutral with regard to jurisdictional claims in published maps and institutional affiliations. 